J. Lake Sci. (湖泊科学) , 2007, 19(5):537-543

http:// www. jlakes. org. E-mail: jlakes@ niglas. ac.cn

(c) 2007 by Journal of Lake Sciences

\title{
太湖流域土地利用变化的水文响应模拟"
}

\author{
李恒鹏, 杨桂山, 金 洋 \\ (中国科学院南京地理与湖泊研究所, 南京 210008)
}

\begin{abstract}
摘 要: 以城市化快速发展的太湖流域为研究对象, 采用 1985 、1995 和 2000 年 TM/ETM 土地利用解译资料, 应用区域尺 度单元格网分布式水文模型,进行长序列水文模拟, 定量评估太湖流域土地利用变化及其水文响应特征, 为流域用地规 划、水资源管理以及灾害防治提供决策参数. 研究显示, 自 1985 年到 2000 年,太湖流域城镇面积扩展了 $40.38 \%$,增加量 占太湖流域总面积的 3.88\% . 在 $1980-2000$ 年的雨情下, 全流域土地利用变化导致产流量平均增加 $4.11 \%$, 约为 $7.56 \times$ $10^{8} \mathrm{~m}^{3}$, 最高值为 $11.76 \%$, 约为 $10.0 \times 10^{8} \mathrm{~m}^{3}$. 受土地利用变化空间差异影响, 产流量增加具有较大区域差异, 城镇快速扩 展的苏锡常地区和浦东浦西地区,土地利用变化导致产流量平均增加为 $10.07 \%$ 和 $7.03 \%$,最高增量达 $20 \%-30 \%$.

关键词:太湖流域;土地利用;分布式水文模型;径流;STREAM
\end{abstract}

\section{Simulation of hydrological response of land use change in Taihu Basin}

\section{Hengpeng, YANG Guishan \& JIN Yang}

( Nanjing Institute of Geography and Limnology, CAS, Nanjing 210008, P. R. China)

\begin{abstract}
Land use changes alter the hydrological characteristics of the land surface, and have significant impacts on hydrological cycle and water balance. Therefore, it's very important to study hydrologic response of land use changes for analyzing the complex effects of human activities on natural systems and improving water resource management and flood control. The distributed hydrological model is the key tools that can be used to give insight in the hydrological impacts of land use changes. This paper selects Taihu Basin as study area, with high-speed urbanization. Historical land use scenarios for 1985 , 1995 , and 2000 were analyzed to track land use change by TM/ETM image explanation and spatial analysis of Arcgis software. The STREAM model, a cell-based distributed hydrological model, was applied to estimate hydrological response of land use changes by simulating the monthly and annual runoff using long-term rain records from 1980 to 2000. For the entire basin between 1985 and 2000, the urban area increased about $40.38 \%$, about $3.88 \%$ of the whole basin area. The land use changes result in an increase of $7.56 \times 10^{8} \mathrm{~m}^{3}$ on average and $10.0 \times 10^{8} \mathrm{~m}^{3}$ on maximum, about $4.11 \%$ and $11.76 \%$ of the whole basin runoff volume respectively. Hydrological response varies according to the extent of land use changes in different parts of the basin. In Suzhou-Wuxi-Changzhou and Pudong-Puxi sub-region, with more extent of land use changes, the land use changes result in an increase of $10.07 \%$ and $7.03 \%$ respectively on average, and $20 \%-30 \%$ on maximum.
\end{abstract}

Keywords: Taihu Basin; land use; distributed hydrological model; runoff; STREAM

土地利用变化改变流域下垫面水文特性,对水循环及水量平衡产生极大影响,并产生一系列的水资源、 水灾害和生态环境问题, 表现为下游洪水灾害加剧、地下水补给减少、水位下降、水资源短缺、湿地退化 等 ${ }^{[1]}$. 研究土地利用的水文响应过程,分析人类活动对自然环境的复杂影响、对水资源管理和灾害防治具 有重要的指导意义. 近年来,随着 GIS 技术、分布式水文模拟技术的发展,为土地利用变化的水文响应研究 提供了大量的科学分析工具,包括 SWAT、TOPMODEL、SHE、TOPKAPI、GSSHA、SVAT 等. 由于这些模型涉及

* 中国科学院知识创新重要方向性项目 (KZCX3 - SW - 331)、国家自然科学基金 (40401056) 和 “973 计划” 课题 (2002CB412310) 联合资助. 2006-08-25 收稿; 2006-12-21 收修改稿. 李恒鹏,男,1973 年生,博士,副研究员:

E-mail:hpli@ niglas. ac.cn. 
大量的流域水文、下垫面特征参数,计算复杂,较难实施, 限制了大区域、长序列的水文模拟分析和应用,已 有研究多选择典型小流域,探讨分布式水文模型的应用效果 ${ }^{[2-5]}$, 并分析代表性小流域用地方式变化对特 征暴雨事件的影响 ${ }^{[6-8]}$. 本文针对区域尺度土地利用变化的水文响应评估,拟选择土地利用高度集约化、城 市化快速发展的太湖流域,采用结构相对简单的大尺度分布式水文模型,通过模拟不同时期土地利用条件 下的产流变化,定量评估 80 年代以来太湖流域城市化过程的水文响应特征, 为流域用地规划、水资源管理 以及灾害防治提供决策参数.

\section{1 研究区域}

太湖流域位于长江尾问与杭州湾之间,三面临江滨海,一面环山, 北抵长江, 东临东海,南滨钱塘江,西 以天目山、茅山等山区为界, 流域面积为 $36895 \mathrm{~km}^{2}$, 约占全国土地面积的 $0.4 \%$. 地势呈西部高东部低, 地貌类型包括山地丘陵及平原, 山地丘陵面积约占 $25 \%$, 主要分布于流域西部; 平原约占 $75 \%$, 分布于流域 北部、东部和南部, 是太湖流域的主体, 高程在 2-9 m. 流域气候属亚热带季风气候, 年平均降雨量约为 $1010-1400 \mathrm{~mm}$, 自北向南逐渐增加, 受地形影响, 降雨量最大地区位于西南部的天目山区, 降水集中于 $4-$ 9 月. 流域地带性土壤为黄棕壤和红壤, 农业土壤主要为水稻土.

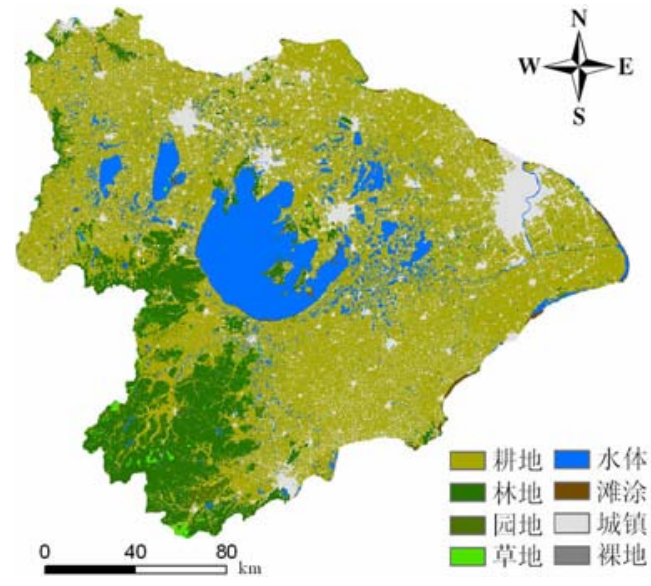

图 1 太湖流域 2000 年土地利用分布

太湖流域行政隶属于江苏、浙江、安徽和上海 3 省 1 市,包括上海、苏州、无锡、常州、杭州、嘉兴和湖州等 地区,历来是我国土地利用集约化程度高, 经济发展最 为快速的地区之一,也是洪水灾害最为严重的地区. 自 20 世纪 80 年代以来, 太湖流域城市化进程不断加快, 据 2000 年的 TM/ETM 土地利用解译结果,城镇用地面 积已占全流域的 $13.50 \%$.与城市化发展相对应, 20 世 纪 90 年代太湖流域洪水灾害频繁发生,除 1992、1994、 2000 年以外,太湖流域均出现超警戒水位的洪水,平 均不到两年就发生一次洪水. 其中 1991、1999 年发生 特大洪涝灾害, 损失超过百亿元人民币 ${ }^{[10]}$.

\section{2 研究方法}

\subsection{STREAM 分布式水文模型}

STREAM( Spatial Tools for River Basin Environment

Fig. 1 The land use distribution of Taihu Basin in 2000

Analysis and Management)模型是基于单元格网的分布式水文模型,能够反映下垫面因子的空间分布对流域 降雨径流形成的影响,揭示人类活动改变下垫面对水循环的复杂影响 ${ }^{[11]}$. 模型针对大尺度流域水文模拟的 应用目标,充分利用易于获取的水文、气象和下垫面等地理信息,采用相对简单的计算方法,可以进行日、月 和年不同时间尺度的模拟. 模型采用意义明确的 BLAISE 脚本语言进行开发,实现模型与 GIS 环境的完全集 成,便于根据应用目标对模型进行完善和扩展,适用性强. 在欧洲的莱茵河流域、印度克利斯那天流域、越南 的香水河流域等大流域均有较为成功的应用 ${ }^{[12-14]}$.

模型采用 Deursen 和 Kwadijk 1994 年在莱茵河流域发展的 RHINEFLOW 模型的基本结构,是以蓄满产 流为概念结构的降水径流模型,适合应用于太湖流域. 模型包括融雪过程、蒸发量过程、土壤水平衡、地下水 平衡等过程,模型的运算采用 GIS 的单元格网运算方法,单元格网水量平衡描述如下:

$$
\begin{aligned}
& R_{(x, y, t)}=P_{(x, y, t)}+A E_{(x, y, t)}+\mathrm{d} S_{(x, y, t)} \\
& S_{(x, y, t)}=S S_{(x, y, t)}+G W S_{(x, y, t)}+S N S_{(x, y, t)}
\end{aligned}
$$

式中, $(x, y)$ 代表格网的位置, $R$ 为径流, $P$ 为降水, $A E$ 为实际蒸发量, $S$ 为储水量, $\mathrm{d} S$ 为储水量的变化, $S S$ 为 土壤含水量和浅层地下水含水量, $G W S$ 为深层地下水含水量, $S N S$ 为积雪量. 潜在蒸发量考虑了植被类型及 土地利用信息,采用较为常用的 Thornthwaite 蒸散发公式进行计算; 实际蒸发量考虑了降水补给、土壤最大 持水量和土壤含水量; 土壤水平衡主要考虑蒸发量、土壤最大持水量和下渗补给地下水量;地下水平衡主要 
包括下渗量、出流量. 模型各模块计算方法参阅文献 [15].

\section{2 数据整理与模型建立}

为了综合认识太湖流域土地利用变化的水文影响,拟采用长序列模拟的方法,模拟时间以月为基本单 位. 由于太湖流域降水主要形式为降雨, 故针对研究区雨情对模型进行调整, 去掉融雪计算模块, 并采用 BLAISE 脚本语言重新建立模型运算代码. 模型运行需要月降水量、月平均温度、土地利用、土壤质地、地形 坡度、流向等流域水文、气象和下垫面信息. 各流域特征信息均需要网格离散化处理,本文选择 Albers 等面 积投影作为各输人图层的数学基础,投影的椭球体采用我国较常用的克拉索夫椭球体参数,格网的大小设 置为 $300 \mathrm{~m}$, 共计 721146 个网格, 较大的格网设置可以提高运算速度,但是较大格网会因内部均化损失细节 信息, 本研究设置 $300 \mathrm{~m}$ 网格是由于这一尺度能够保留分散居民点信息.

流域月降水量、月平均温度采用研究区及周边地区 $1979-2000$ 年共计 13 个气象站的实测序列,应用 反距离加权平均插值 (IDW, Inverse distance weighted interpolation) 方法,生成 22 年共计 264 个月份的各月降 雨量和平均温度栅格图,并采用同样的插值方法生成 12 个月的多年月平均温度栅格图,在此基础上应用 GIS 地图代数运算功能计算获得研究区热力指数 $H$ 的分布图. 数字地形采用 1:50000 地形图数字化建立, 并转换为 $300 \mathrm{~m}$ 的网格与其它流域信息保持一致. 应用 IDRISI 的地形分析模块计算获得坡度分布图和流向 分布图,坡度单位采用度,流向采用 8 方向划分方法,分别用 $1 、 2 、 4 、 8 、 16 、 32 、 64$ 和 128 代表,用于流域率定 和验证的集流运算中. 土地利用数据采用 TM/ETM 卫星影像目视解译结果, 由于在 22 年的模拟时间中, 土 地利用分布有明显变化,故不同时间段采用相应时间的土地利用数据,其中 $1979-1989$ 采用 1985 年的土 地利用解译数据, $1990-2000$ 采用 1995 年的土地利用解译数据. 根据模型手册中不同土地利用类型或植被 类型对应的作物指数值, 建立作物指数 $K_{c}$ 分布栅格图. 土壤数据采用 $1: 500000$ 土壤类型分布图, 土壤质地 根据土壤志中各土壤类型的粒度组成确定, 采用国际标准质地分类方法, 并根据模型手册及相关研究成果 中质地类型与最大持水量的参考值进行转换, 获得土壤最大持水量 $W H C$ 分布图. 主要下垫面水文要素栅格 图层如图 2.
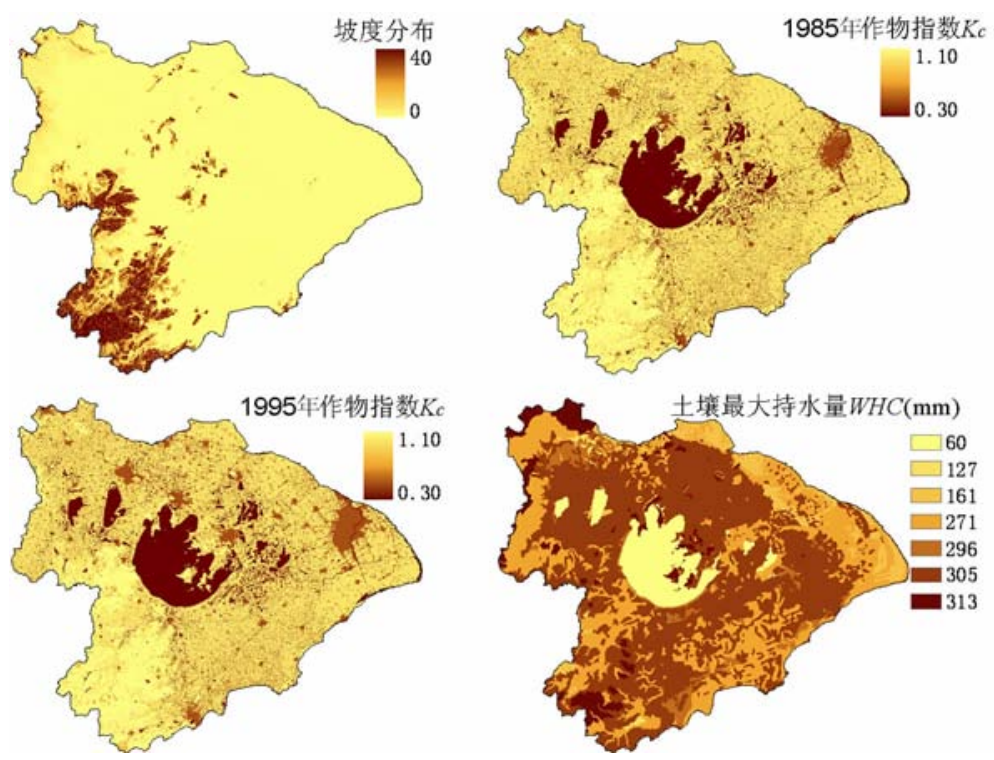

图 2 模型下垫面主要水文参数分布图(坡度、作物指数、最大持水量)

Fig. 2 Hydrologic parameter maps of land surface for model (including slope, crop factor, water holding capacity)

\section{3 模型率定和验证}

由于太湖流域为人工控制流域, 仅有西南部的西苕溪流域保持较好的自然特征,而且水力关系明晰, 故 
选择西苕溪流域进行模型参数率定和验证,径流序列采用西苕溪流域下游范家村水文站的实测序列, 控制 流域面积为 $1950 \mathrm{~km}^{2}$. 模型运行时间设定为 1979-2000 年,其中 1979 年为模型预热期, 目标是确定合适的 初始值;1980 - 1989 年为模型参数率定期,采用 1985 年土地利用数据; $1990-2000$ 年为模型验证期,采用 1995 年土地利用数据. 为了检验模型模拟整个太湖流域产流量的精度,采用全流域代表性暴雨实测和计算 结果进行比对,拟选择 1991、1999 年太湖流域管理局产水量计算结果进行验证 ${ }^{[16,17]}$.

初始值通过模型循环初步确定,并采用 1979 年作为模型预热阶段,获得 1980 年的初始值, 率定参数包 括作物指数 $K_{c}$ 、地形指数 $C$ 、最大持水量 $W H C$ 、热力指数 $H$ 分布式栅格图,均有明确的物理意义, 根据实际 数据确定. 应用 “试错法” 和 “自动参数估算法” 相结合的方法获取最佳参数. 模型控制产流量的主要参数为 作物指数 (影响蒸发及截留) 和热力指数, 首先通过试错法将总产流量率定到接近实测的范围, 然后通过自 动率定方法系统地调整参数使模型计算值 (径流量) “最佳” 逼近观测值, 提高率定效率. 应用率定参数模拟 $1990-2000$ 年的产流量, 与实测值进行比较, 检验模型的稳定性. 将率定参数应用到全流域, 模拟 $1980-$ 2000 年的全流域各月产流量, 并与太湖流域管理局计算结果进行比较, 检验模型对整个太湖流域产流的预 测能力.

图 3 为模型率定期和验证期计算值与观测值的比较结果, 总体来看, 月径流量模拟值与观测值吻合良 好. 模型率定期月径流量确定性系数为 0.76 , 年径流量平均误差仅为 $8 \%$; 模型验证期月径流量的确定性系 数为 0.74 , 年径流量平均误差为 $13 \%$, 证实模型的稳定性良好, 具有较好的预测能力. 比较模拟值与实测值 的差异发现,模型对春季径流低峰模拟效果稍差, 主要是因为该区上游建有老石坎水库和赋石水库两个大 型水库,各支流上也分布有较多的小型水库,对径流的人为调节较大. 采用率定参数计算 $1980-2000$ 年的 整个太湖流域的产流量,将 1991 年 5-9 月、1999 年 5-9 月计算结果分别与太湖流域管理局同期计算结果 进行比较,两者差异分别为 $18.9 \% 、 16.0 \%$,均在 $20 \%$ 以内,证实模型在太湖流域径流量模拟中具有较好的 应用效果.
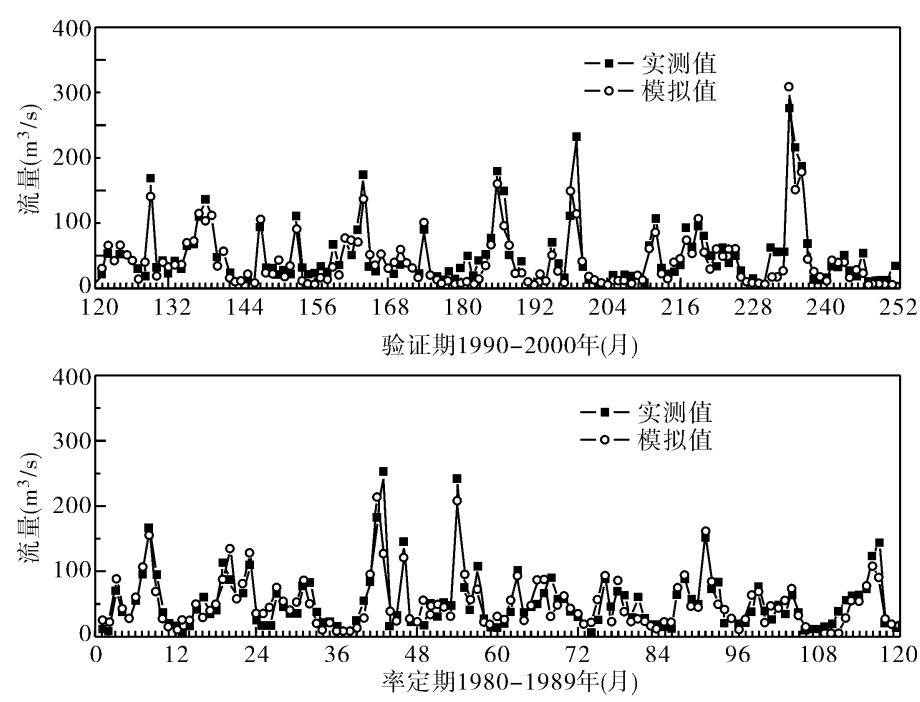

图 3 月径流量模拟值与实测值比较

Fig. 3 Comparison of modelled and observed monthly runoff

\section{3 研究结果}

为分析流域土地利用变化的水文响应,拟选择 1985 与 2000 年的土地利用数据,采用 $1980-2000$ 年的 雨情,应用单元格网分布式水文模型分别计算两个时期土地利用的产流差异,揭示太湖流域土地利用的水 文响应. 


\section{1 太湖流域土地利用变化特征}

采用 TM/ETM 影像目视解译方法,提取 1985 和 2000 年土地利用分布信息,利用 GIS 空间叠加功能分 析近 15 年来土地利用变化特征, 土地利用类别分为林地、耕地、园地、草地、水体、湿地、城镇用地和裸地 8 类. 表 1 为土地利用变化的统计结果,可以看出自 1985 到 2000 年,流域土地利用有较大变化,变化的主要 趋势是城镇用地不断扩展,增加的面积主要来源于耕地. 1985 年占流域面积 $9.62 \%$ 的城镇用地到 1995 年 增长为 $13.50 \%$,城镇扩展了 $40.3 \%$, 增加量占太湖流域的总面积的 $3.88 \%$, 同期耕地面积减少量占太湖流 域总面积的 $4.17 \%$.其它用地面积变化相对较少.

表 $11985-2000$ 土地利用结构比较及变化量

Tab. 1 Changes in different land use categories as percentage of total basin area

\begin{tabular}{|c|c|c|c|c|c|c|}
\hline \multirow{2}{*}{$\begin{array}{c}\text { 土地利用 } \\
\text { 类型 }\end{array}$} & \multicolumn{2}{|c|}{1985 年土地利用结构 } & \multicolumn{2}{|c|}{2000 年土地利用结构 } & \multicolumn{2}{|c|}{$1985-2000$ 年土地利用变化 } \\
\hline & 面积 $\left(\mathrm{hm}^{2}\right)$ & 百分比 & 面积 $\left(\mathrm{hm}^{2}\right)$ & 百分比 & 面积 $\left(\mathrm{hm}^{2}\right)$ & 百分比 \\
\hline 耕地 & 2369100 & $63.72 \%$ & 2214135 & $59.55 \%$ & -154965 & $-4.17 \%$ \\
\hline 林地 & 474453 & $12.76 \%$ & 467856 & $12.58 \%$ & -6597 & $-0.18 \%$ \\
\hline 园地 & 22617 & $0.61 \%$ & 30627 & $0.82 \%$ & 8010 & $0.22 \%$ \\
\hline 草地 & 18396 & $0.49 \%$ & 20052 & $0.54 \%$ & 1656 & $0.04 \%$ \\
\hline 水体 & 456075 & $12.27 \%$ & 463266 & $12.46 \%$ & 7191 & $0.19 \%$ \\
\hline 湿地 & 18144 & $0.49 \%$ & 18657 & $0.50 \%$ & 513 & $0.01 \%$ \\
\hline 城镇 & 357525 & $9.62 \%$ & 501903 & $13.50 \%$ & 144378 & $3.88 \%$ \\
\hline 裸地 & 1494 & $0.04 \%$ & 1305 & $0.04 \%$ & -189 & $-0.01 \%$ \\
\hline
\end{tabular}

\section{2 太湖流域土地利用变化对产流量的影响}

采用 $1980-2000$ 年的雨情, 模拟并比较 1985 和 2000 年土地利用的产流差异. 图 4 柱状图为太湖流域 内各气象站 $1980-2000$ 年的平均年降雨序列, 线状图分别为产流增加量和增加百分数. 对各年模拟结果进 行统计,结果显示 $1985-2000$ 年全流域土地利用变化导致产流量平均增加 $4.11 \%$,约为 $7.56 \times 10^{8} \mathrm{~m}^{3}$, 最 高值为 $11.76 \%$, 约为 $10.0 \times 10^{8} \mathrm{~m}^{3}$, 其中上游人湖量平均增加 $3.64 \%$, 约为 $2.07 \times 10^{8} \mathrm{~m}^{3}$, 最高值为 $10.13 \%$,约为 $3.37 \times 10^{8} \mathrm{~m}^{3}$. 不同年份雨情条件下产流增加量不同, 与降雨量不呈线形关系. 导致差异主要 有两个原因,其一是降雨分布差异的影响,由于不同地区土地利用变化空间差异明显,当降雨中心与土地利 用变化显著地区覆合时,产流量增加明显, 反之增加量较少; 其二是降雨强度差异的影响, 由于研究区产流

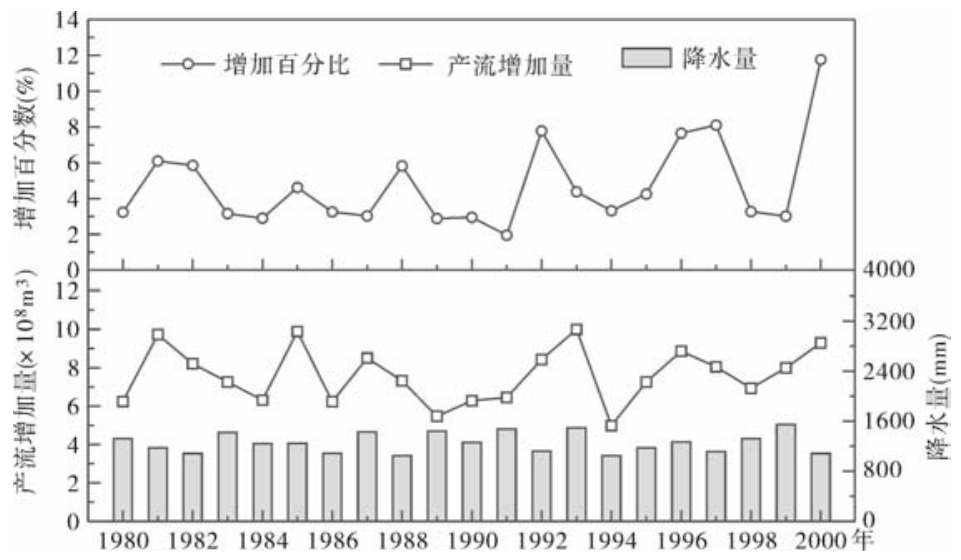

图 4 太湖流域土地利用变化对年产流量影响

Fig. 4 Changes in annual runoff volume due to landuse changes in Taihu Basin 
方式以蓄满产流为主, 太湖流域土地利用变化主要表现为城镇用地增加, 在较大强度降雨条件下, 各用地方 式均已蓄满, 城镇用地和其它用地相比较产流增加量相对较少, 而较小强度的雨情条件, 城镇用地不透水面 积较大, 以地表产流为主, 产流较大, 其它用地类型尚未蓄满, 径流以壤中流或地下水为主, 产流量较少, 城 镇用地和其它用地相比较产流增加量较多.

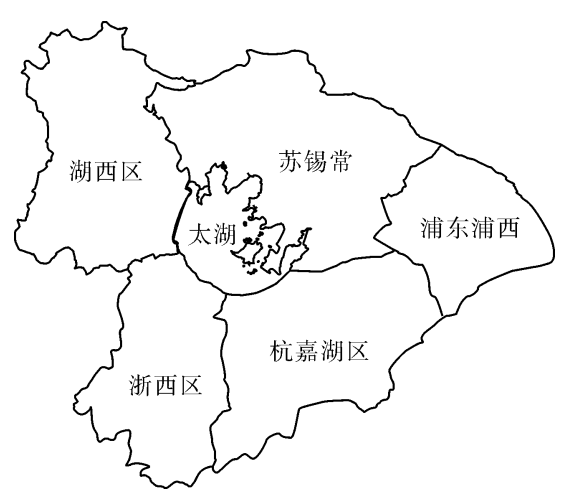

图 5 太湖流域分区图

Fig. 5 Region divisions of Taihu Basin

\section{3 土地利用变化水文响应的空间差异}

受土地利用变化的区域差异影响, 不同区域水文响应特 征不同. 结合水利分区与土地利用分布特点, 将太湖流域分为 6 个区, 分别为湖西区、浙西地区、苏锡常地区、杭嘉湖地区、太 湖和浦东浦西区. 统计除太湖以外的各区城镇扩展率及产流 增加量, 其中城镇扩展率采用扩展面积占相应分区总面积的 百分数来表示. 统计结果如表 2 所示, 苏锡常地区、浦东浦西 地区土地利用变化最为明显,分别为 $7.72 \%$ 和 $7.07 \%$, 其次为 湖西区, 城镇扩展率为 $4.37 \%$, 其它区域城镇扩展率较小. 各 区土地利用变化的水文响应也有较大差异,其中土地利用变 化导致产流增加最高的区域为苏锡常地区和浦东浦西地区， 年径流量平均增加 $10.07 \%$ 和 $8.34 \%$, 最高可达 $28.93 \%$ 和 $25.66 \%$, 其次为湖西地区, 平均增加 $7.03 \%$, 最高可达到 $24.72 \%$,其它区域变化较小.

表 2 太湖流域不同区域土地利用变化对产流量影响比较

Tab. 2 The comparison of annual runoff volume change for different divisions in Taihu Basin

\begin{tabular}{cccccccc}
\hline 统计项 & 统计值 & 浙西 & 湖西 & 苏锡常 & 浦东浦西 & 杭嘉平原 & 全流域 \\
\hline $\begin{array}{c}\text { 城镇扩展 } \\
\text { 产流增加量 }\end{array}$ & 扩展率 & $0.37 \%$ & $4.37 \%$ & $7.27 \%$ & $7.07 \%$ & $1.42 \%$ & $3.88 \%$ \\
$\left(\times 10^{8} \mathrm{~m}^{3}\right)$ & 最大值 & 0.18 & 3.21 & 4.78 & 2.33 & 0.63 & 10.00 \\
& $\begin{array}{c}\text { 最小值 } \\
\text { 平均值 }\end{array}$ & 0.07 & 1.39 & 2.28 & 0.86 & 0.28 & 4.92 \\
\hline 产流增加 & 最大值 & $0.66 \%$ & $24.72 \%$ & $28.93 \%$ & $25.66 \%$ & $5.24 \%$ & $11.76 \%$ \\
比例 $(\%)$ & 最小值 & $0.15 \%$ & $2.03 \%$ & $3.86 \%$ & $3.66 \%$ & $0.58 \%$ & $1.98 \%$ \\
& 平均值 & $0.31 \%$ & $7.03 \%$ & $10.07 \%$ & $8.34 \%$ & $1.13 \%$ & $4.11 \%$ \\
\hline
\end{tabular}

\section{4 结论}

总结以上分析过程与结果, 可以得出以下结论:

(1) STREAM 模型采用基于单元格网的建模思路,充分利用现有较为详实的下垫面基础地理信息,能 够评价区域尺度土地利用/土地覆被变化对水文及水资源的影响. 研究证实模型对揭示太湖流域高强度人 类活动的水文响应具有很好的应用价值.

(2) 采用 $1980-2000$ 年的雨情,比较分析 1985-2000 年太湖流域土地利用变化的水文响应特征. 研 究结果显示, 全流域土地利用变化导致产流量平均增加 $4.11 \%$, 约为 $7.56 \times 10^{8} \mathrm{~m}^{3}$, 最高值为 $11.76 \%$, 约为 $10.0 \times 10^{8} \mathrm{~m}^{3}$, 其中上游人湖量平均增加 $3.64 \%$, 约为 $2.07 \times 10^{8} \mathrm{~m}^{3}$, 最高值为 $10.13 \%$, 约为 $3.37 \times 10^{8} \mathrm{~m}^{3}$. 各年差异与降雨分布和雨情特征有关.

(3) 在太湖流域,以城镇扩展为主的土地利用变化主要集中于城市相对密集的地区, 尽管全流域 1985 -2000 年土地利用变化导致产流平均增加仅 $4.11 \%$, 但是在城镇快速扩展的苏锡常地区和浦东浦西地区, 
土地利用变化导致产流平均增加为 $10.07 \%$ 和 $7.03 \%$,最高增量可达 $20 \%-30 \%$.

致谢: 中科院南京地理与湖泊研究所“湖泊 - 流域基础数据库” 为本项研究提供了部分地理数据, 在此深表 感谢.

\section{5 参考文献}

[1] Budhendra B, Jon H, Bernie E et al. Assessing watershed-scale, long-term hydrologic impacts of land-use change Using a GIS-NPS model. Environmental Management, 2003, 26(6) : 643-658.

[2] 郭太英, 程春田. 基于 TOPMODEL 的分布式水文模型应用研究. 南水北调与水利科技, 2005, 3(4): $47-49$.

[3] 刘志雨. ArcTOP:TOPKAPI 与 GIS 紧密连接的分布式水文模型系统. 水文, 2005, 25(4):18 - 22 .

[4] 张雷娜, 李秀彬, 王兆锋等. 一种可用于表征土地利用变化水文效应的水文模型探讨一 SWAT 模 型在云州水库流域的应用研究. 水文, 2004, 24(3):4-8.

[5] 郑红星, 刘昌明, 王中根等. 黄河典型流域分布式水文过程模拟. 地理研究, 2004, 23(4):447 - 454.

[6] 史培军, 袁 艺, 陈 晋. 深圳市土地利用变化/土地覆被变化对流域径流的影响. 生态学报, 2001, 21(7): 1041 - 1049.

[7] Liu Y B, Smedt F D, Hoffmann L et al. Assessing land use impacts on flood processes in complex terrain by using GIS and modeling approach. Environmental Modeling and Assessment, 2004, 9(4) :227 - 235.

[8] Kim Y, Engel B, Lim K et al. Runoff impacts of land use change in the Indian river lagoon watershed. Journal of Hydrologic Engineering, 2002, 7(3):245 - 251

[9] 高俊峰. 太湖流域土地利用变化及洪涝灾害响应. 自然资源学报, 2002, 17(2): 150-156.

[10] 高俊峰, 闻余华. 太湖流域土地利用变化对流域产水量的影响. 地理学报, 2002, 57(2):194-200.

[11] Aerts J, Kriek M, Schepel M. STREAM, spatial tools for river basins and environment and analysis of management options: 'setup and requirements'. Physics and Chemistry of the Earth, 1999, 24(6) : 591 - 595.

[12] Middelkoop H, Daamen K, Gellens D et al. Impact of climate change on hydrological regimes and water resources management in the Rhine Basin. Climatic Change, 2001, 49(1/2) : $105-128$.

[13] Horritt M S, Mason D C. Flood boundary delination from synthetic aperture radar imagery using a statistical active contour model. International Journal of Remote Sensing, 2001, 22(13):2489 - 2507.

[14] Aerts J, Hassan A, Savenije H et al. Using GIS tools and rapid assessment techniques for determining salt intrusion: STREAM, a river basin management instrument. Physics and Chemistry of the Earth(Part B), $200025(3): 265-273$.

[15] Aers J, Bouwer L, Geel G et al. Spatial tools for river basins and environment and analysis of management. User Manual, version 3.0, Institute for Environmental Studies, Vrije University, 2005.

[16] 吴浩云, 管惟庆. 1991 年太湖流域洪水. 北京: 中国水利水电出版社, $2000: 95-96$.

[17] 欧炎伦, 吴浩云, 林荷娟等. 1999 年太湖流域洪水. 北京: 中国水利水电出版社, 2001: $74-75$. 